Pobrane z czasopisma Annales H - Oeconomia http://oeconomia.annales.umcs.pl Data: 26/04/2023 14:29:10

DOI:10.17951/h.2017.51.5.139

\begin{tabular}{lcl}
\hline & A N N A L E S \\
UNIVERSITATIS MARIAE CURIE-SKŁODOWSKA \\
LUBLIN - POLONIA \\
VOL.LI, 5 & SECTIOH H \\
\hline
\end{tabular}

University of Warsaw. Faculty of Management

RENATA KARKOWSKA

rkarkowska@wz.uw.edu.pl

\title{
The Relevance of Foreign Ownership and Financial Liberalization for Determining Banking Risk: A Comparative Analysis of European Countries
}

\footnotetext{
Znaczenie zagranicznego kapitału właścicielskiego i liberalizacji finansowej dla ryzyka bankowego: analiza porównawcza w krajach europejskich
}

Keywords: banking; stability, risk adjusted ROA; financial freedom; foreign ownership; developing countries

Słowa kluczowe: bankowość; stabilność, ROA ważone ryzykiem; liberalizacja finansowa; kapitał zagraniczny; kraje rozwijające się

JEL Code: F36; G2; G21; G34

\section{Introduction}

Reversal of financial market integration in Europe during the global financial crisis requires tools to measure and monitor banking sector stability. Banking sectors in Europe, especially in Central and Eastern countries, are characterized by a significant share of foreign capital and height level of concentration. This phenomenon may enhance the financial institutions to compete and probably take more risk causing banking sector more instable. The question whether foreign capital influences the stability of banks is examined by an extensive literature and provides mixed results. Another important question is whether the risk determinants are the same in 
a cross-country analysis and for different stages of country development. Important feature of the banking sectors of CEE countries is that banks are relatively small in comparison to the advanced. To verify the above we concern different sub-groups: advanced economies vs. emerging economies.

We aim to throw some light on these aspects, and specifically address three main questions in our empirical analysis: i) the changes in foreign ownership in banks as the channel of influence on risk in banking sector, ii) the relevance of economic development in the country for determining stability of bank risk, iii) the relative importance of changes in bank risk-taking promoted by financial liberalization. The study provides important findings that banks' risk-taking is driven by different sets of determinants across European countries, so regulators could not design the same strategies to limit systemic risk for advanced and emerging markets. Based on the empirical literature, identification of banking risk determinants in the Central and Eastern Europe banking sector appears to be limited. The international regulatory framework of the banking sector, which is dedicated to advanced economies, may not have application in emerging markets.

Taking into account the incompleteness of banking sector instability, this paper adopts a combined approach and presents adjusted return on assets ratio, which can form the basis of risk-taking by banks in two groups of countries: advanced, and developing in Europe.

The contribution of this study is as follows: firstly, based on the research undertaken by Brunnermeier and Pedersen [2009], Demirgüc-Kunt and Detragiache [1999] and Brewer, Kaufman and Larry [2008], we present a bank's efficiency ratio that can contribute to changing and growing instability of individual banks and the entire financial system. We document trends in the relative importance of risk ratio for a large sample of international banks over 10 years to take into account the impact of the business cycle in systemic risk fluctuation. Still open is the question of the pro-cyclical nature of systemic risk [see: Borio, Furfine, Lowe, 2001]; secondly, the study explores the implications of the interaction between bank risk-taking and a range of determinants in different countries. The empirical study on the determinants of banking risk diversification will answer the question of which factors were omitted in previous studies and which factors - foreign capital ownership, financial liberalization, or macroeconomic conditions - implicate significant impulses for systemic risk spread; finally, we assess what differences of banking risk determinants are associated with countries at different levels of economic development.

\section{Literature review and hypotheses}

The recent global financial crisis has highlighted the importance of the procyclicality of the banking sector. The phenomenon has transformed banks from mitigation risk to pressures of increase efficiency, potentially affecting financial stability 
in whole sectors. The risk taken by the bank can result from its internal policy, for example, in terms of leverage, the ownership structure, access to foreign financing, or structural and macroeconomic factors. But the reactions of banks can be varied between countries with different levels of development.

\subsection{The impact of the foreign ownership on bank risk}

Moving to ownership structure, many banking systems are dominated by public ownership, but the increasing foreign bank penetration on bank risk and lending, especially in emerging economies, is a significant problem stressed in the literature [Agoraki, Delis, Pasiouras, 2011; Iannotta, Nocera, Sironi, 2013; Jimenez, Lopez, Saurina, 2013]. Bang, Olivero and Wu [2011] use bank-level variable on about 350 foreign subsidiaries of 68 multinational banks in emerging economies, and emphasize evidence of financial crisis transmission of financial shocks from parent banks to foreign subsidiaries, and this is strongest among subsidiaries in Central and Eastern Europe. Anginer, Cerutti and Martínez Pería [2016] examine the relation between the default risk of foreign bank subsidiaries in developing countries and their parents during the global financial crisis and find significant and positive correlation. This is lower in banks which are more independent from their foreign parents. The risky shocks in subsidiaries are also related with host country bank regulations. Dekle and Mihye [2014] find evidence that foreign affliates operating in internal markets reduced their risk in lending by more than the domestic banks located in these regions. The access of foreign banks to funding from parent banks through internal capital markets serves as the most convincing explanation for this situation. The impact of foreign and state ownership on banking risk was investigated by Lassoued, Houda and Ben Rejeb Attia [2016], who find that state ownership banks are encouraged to take more risks while foreign subsidiaries. But on the other hand, state-owned banks increase capital ratio to hedge against excessive risk.

Using data from 35 emerging economies located in Central and Eastern Europe, Latin America and Asia, Wu et al. [2017] investigate whether foreign bank group affects the risk of domestic banks. They find evidence that the banking risk increases with the penetration of foreign investors in the host economy. De Haas and Van Horen [2012] limit lending in many CEE countries, that depend on cross-border credit from Western Europe, transmitting shocks across borders. Regarding its impact on risk-taking, foreign ownership is noticed as a stimulator for risk-taking for several reasons. First, foreign institutions are more efficient and take more risk. Second, foreign banks may show higher preference for risk compared to domestic banks as they can hedge and better diversify risk.

Against the above findings and on the prominent role of foreign banks in most emerging countries, it is expected that ownership stimulates banking risk.

Hypothesis 1: Foreign ownership has a negative influence on bank's stability in developing countries in Europe. 


\subsection{Financial liberalization as the determinant of banking risk-taking}

Financial liberalization is often defined as a measure of banking efficiency as well as a measure of independence from government control and interference in the financial sector. Our paper also contributes to studies on the impact of financial liberalization on the risk in the banking sector. Research on a negative and positive influence of financial openness on risk or efficiency were conducted by Cubillas and González [2014], Luo, Tanna and De Vita [2016]. The literature traditionally highlights that financial liberalization is the main determinant of banking risk showing several channels [Demirgüc-Kunt, Detragiache, 1999; Kaminsky, Reinhart, 1999]. Financial liberalization usually implies the reduction of controls on international capital movements, and more restrictions on bank activities have been viewed by regulators as a useful tool for reducing bank risk [Hovakimian, Kane, 2000]. A set of theoretical literature models the relation between financial liberalization and bank risk through increases in risk-taking. This openness for financial institutions to raise foreign currency funding and lending them to local borrowers generate aditional risk [Kaminsky, Reinhart, 1999; Stiglitz, 2000]. Cubillas and González [2014] indicate that financial liberalization implies stronger competition in the banking sector that increases bank risk by expanding possibility in emerging countries and increases risk-taking encouragements in high developed countries. As opposite, the literature on boom-bust cycles suggests that financial liberalization increases banking risk by undertaking riskier investments much more in less economically and developed countries [Tornell, Westermann, Martinez, 2004].

According to these arguments, we expect that financial liberalization has a greater influence on bank risk in developed countries, because poor-quality institutions increase the ability of financial liberalization to expand opportunities to undertake riskier investments. Thus, our hypothesis is as follows:

Hypothesis 2: Financial liberalization has an impact on the increase in risk-taking by banks.

\section{Research design and identification of the banking risk measures}

We use risk adjusted ROA ratio as the bank's stability measure [Amidu, Wolfe, 2013; Ghosh, 2017], calculated as (Eq. 1):

$$
R I S K_{-} A D_{n, i, t}=\frac{R O A_{n, i, t}}{\sigma R O A_{n, i}}
$$

where:

$R I S K_{-} A D_{n, i, t}$ - the ROA ratio adjusted by risk measure in $n$ bank, in $i$ country, at $t$ time

$R O A_{n, i, t}$ - return on assets ratio in $n$ bank, in $i$ country, at $t$ time

$\sigma R O A_{n, i, t}$ - standard deviation of ROA in $n$ bank, in $i$ country, at $t$ time 
The choice of risk adjusted ROA variable is in line with the general concept that foreign capital brings innovation and efficiency, reduces costs, which translates into higher rates of return.

We test for the interaction between the bank risk and its factors using a basis panel regression model presented as (Eq. 2):

$$
\begin{aligned}
& R I S K_{-} A D_{n, i, t}=\beta_{1} R I S K_{-} A D_{n, i, t-l}+\beta_{2} S_{2} E_{n, i, t}+\beta_{3} L O A N S \_A S S E T S_{n, i, t}+\beta_{4} \text { FOREIGN_BANKS }_{i, t} \\
& +\beta_{5} \text { FINACIAL_FREE }_{i, t}+\beta_{8} \text { INFLATION }_{i, t}+\beta_{9} \text { GDP_GROWTH }_{i, t}+\varepsilon_{i, t}
\end{aligned}
$$

where:

$Y_{n, i, t}$ - the $\mathrm{n}$-th bank risk measure, calculated as $R I S K_{-} A D_{n, i, t}$ (Eq. 1) for bank risk in i-th country, observed in $t$ period

$l$ - number of lags for dependent variable

$\beta$ - the regression coefficient (the measure of sensitivity of bank risk)

$S I Z E_{n, i t}-\operatorname{logarithm}$ of total bank's assets

LOANS_ASSETS $S_{n, i, t}$ - as the ratio of bank's total loans to assets (\%), as a measure of bank's activity

At the national level, we control foreign ownership, financial freedom, real GDP growth, and inflation.

FOREIGN_BANKS ${ }_{i, t}$ - foreign bank assets among total bank assets (\%), in $i$ country, at $t$ time

FINANCIAL_FREE $E_{i, t}$ - financial freedom index, in $i$ country, at $t$ time

We use the Index of Financial Reforms of Abiad, Detragiache and Tressel [2008], the Financial Freedom component of the Index of Economic Freedom from the Heritage Foundation. Financial freedom is a measure of the extent of government regulation of financial services; the difficulty of opening and operating financial services institutions. The index assigns an overall score on a scale of $0-100$, and it equals 0 for prohibited financial institutions, and 100 where government influence is negligible. Higher values of the index indicate greater financial freedom.

$I_{\text {INFLATION }}$ - inflation rate (Financial Structure Dataset, World Bank), in $i$ country, at $t$ time

GDP_GROWTH ${ }_{i, t}$ - annual growth rate of real GDP [Angkinand, Wihlborg, 2010] (Financial Structure Dataset, World Bank), in $i$ country, at $t$ time

$\varepsilon_{j, t}-$ a random component

To test our hypotheses, this study applies a two-step GMM robust estimator for panel on individual banks [Arellano, Bond, 1991; Blundell, Bond, 1998]. Furthermore, I used several tests proposed by Arellano and Bond [1991] and Arellano and Bover [1995] to evaluate the general model. The first is the Hansen test of over-iden- 
tifying restrictions, which tests the overall strength of the instruments for a two-step estimator [Arellano, Bond, 1991; Blundell, Bond, 1998]. As instrumentals there were used lagged dependent variables. All regression parameters are provided with the level of significance, which should facilitate interpretation of results. I used the Arellano-Bond tests for AR(1) and AR(2) in first differences.

Through a dataset, that covers 381 European banks spanning the 1995-2015 period and the methodology of panel regression, the empirical findings document the determinants of banking risk-taking. The full range of banks from 27 countries is divided into two groups: i) 20 advanced European countries (Austria, Belgium, Cyprus, Denmark, Finland, France, Germany, Greece, Iceland, Ireland, Italy, Luxembourg, Malta, the Netherlands, Norway, Portugal, Spain, Sweden, Switzerland, the United Kingdom), ii) 7 developing countries of CEE (the Czech Republic, Estonia, Hungary, Latvia, Slovakia, Slovenia, Poland). I compute the measure of bank's risk using the Bankscope database. Macroeconomic variables are obtained from the database: OECD Statistics, and the World Bank.

Tab. 1. Summary statistics

\begin{tabular}{|l|c|c|c|c|c|c|c|}
\hline & RISK_AD & SIZE & $\begin{array}{c}\text { LOANS_- } \\
\text { ASSETS }\end{array}$ & $\begin{array}{c}\text { FOREIGN_ } \\
\text { BANKS }\end{array}$ & $\begin{array}{c}\text { FINANCIAL_- } \\
\text { FREE }\end{array}$ & $\begin{array}{c}\text { GDP_- } \\
\text { GROWTH }\end{array}$ & INFLATION \\
\hline mean & 1.18 & 15.74 & 0.94 & 37.05 & 68.50 & 2.39 & 9.28 \\
\hline sd & 2.15 & 2.43 & 14.91 & 33.05 & 15.30 & 2.71 & 41.29 \\
\hline $\max$ & 82.29 & 20.71 & 0.99 & 100.00 & 95.00 & 10.06 & 58.65 \\
\hline $\min$ & -4.79 & 4.06 & 0.00 & 0.00 & 10.00 & -8.99 & 1.06 \\
\hline
\end{tabular}

Note: The symbols have the following meaning: RISK_AD - adjusted risk is given by Eq. 1, SIZE - logarithm of total bank's assets, LOANS_ASSETS - as the ratio of bank's loans to total assets (\%), FOREIGN_BANKS - foreign bank's assets among total bank's assets (\%), FINANCIAL_FREE - financial freedom is a measure of banking efficiency (\%), GDP_GROWTH - GDP annual rate (\%), INFLATION - inflation rate.

Source: author's own study.

Tab. 1 reports the descriptive statistics for the whole sample of 381 . The average value for the RISK_AD variable is $1.18 \%$, with the standard deviation $2.15 \%$. Average foreign bank ownership is $37 \%$, and ranges from 0 to $100 \%$. Regarding financial freedom structure varies from 10 to $95 \%$, on average $68.5 \%$. Tab. 2 reports correlations for bank-level variable, foreign ownership, financial liberalization, and macroeconomic variables. Adjusted risk ratio shows positive correlation between: SIZE, FINANCIAL_FREE, GDP_GROWTH and the negative correlation between the variables of LOANS_ASSETS, FOREIGN_BANKS and INFLATION.

Tab. 2. Correlation matrix

\begin{tabular}{|l|c|c|c|c|c|c|c|}
\hline & RISK_AD & SIZE & $\begin{array}{c}\text { LOANS_ } \\
\text { ASSETS }\end{array}$ & $\begin{array}{c}\text { FOREIGN__ } \\
\text { BANKS }\end{array}$ & $\begin{array}{c}\text { FINANCIAL_ } \\
\text { FREE }\end{array}$ & GDP & INFLATION \\
\hline RISK_AD & 1.00 & & & & & & \\
\hline SIZE & $0.08^{* * *}$ & 1.00 & & & & & \\
\hline & $(0.00)$ & & & & & & \\
\hline
\end{tabular}


Pobrane z czasopisma Annales H - Oeconomia http://oeconomia.annales.umcs.pl

Data: 26/04/2023 14:29:10

THE RELEVANCE OF FOREIGN OWNERSHIP AND FINANCIAL LIBERALIZATION...

\begin{tabular}{|l|c|c|c|c|c|c|c|}
\hline & RISK_AD & SIZE & $\begin{array}{c}\text { LOANS_ } \\
\text { ASSETS }\end{array}$ & $\begin{array}{c}\text { FOREIGN_ } \\
\text { BANKS }\end{array}$ & $\begin{array}{c}\text { FINANCIAL_ } \\
\text { FREE }\end{array}$ & GDP & INFLATION \\
\hline LOANS_ASSETS & $0.03^{* * * *}$ & $-0.08^{* *}$ & 1.00 & & & & \\
\hline & $(0.10)$ & $(0.01)$ & & & & & \\
\hline FOREIGN_BANK & $-0.03^{*}$ & $-0.38^{* * *}$ & $-0.02^{* * *}$ & 1.00 & & & \\
\hline & $(0.04)$ & $(0.00)$ & $(0.50)$ & & & & \\
\hline FINANCIAL_FREE & 0.01 & $0.35^{* * *}$ & -0.03 & $-0.03^{*}$ & 1.00 & & \\
\hline & $(0.55)$ & $(0.00)$ & $(0.34)$ & $(0.03)$ & & & \\
\hline GDP_GROWTH & $0.05^{* * *}$ & $-0.26^{* * *}$ & $0.01^{* * *}$ & $0.21^{* * *}$ & $-0.22^{* * *}$ & 1.00 & \\
\hline & $(0.00)$ & $(0.00)$ & $(0.42)$ & $(0.00)$ & $(0.00)$ & & \\
\hline INFLATION & $0.05^{* * * *}$ & $-0.15^{* * *}$ & 0.01 & $0.05^{* * *}$ & $-0.15^{* * *}$ & $0.05^{* * *}$ & 1.00 \\
\hline & $(0.00)$ & $(0.00)$ & $(0.31)$ & $(0.00)$ & $(0.00)$ & $(0.00)$ & \\
\hline
\end{tabular}

Note: P-values in parentheses, ${ }^{*} p<0.1,{ }^{* *} p<0.05,{ }^{* * *} p<0.01$. The symbols have the following meaning: $R I S K \_A D$-adjusted risk is given by Eq. 1, SIZE - logarithm of total bank's assets, LOANS_ASSETS - as the ratio of bank's loans to total assets (\%), FOREIGN_BANKS - foreign bank's assets among total bank's assets (\%), FINANCIAL_FREE - financial freedom is a measure of banking efficiency (\%), GDP_GROWTH - GDP annual rate (\%), INFLATION - inflation rate.

Source: author's own study.

\section{Empirical results}

In this section, we estimate whether banks' risk-taking is driven by different sets of determinants in advanced and developing countries of Europe (see: Tab. 3). It shows that bank's size has a positive effect on the risk adjusted ratio in developing countries (Model 2), but negative in advanced ones (Model 1). The similar results we obtained in LOANS_ASSETS coefficient - growth of loans influenced positively on RISK_AD in CEE, but negatively in Western Europe banks. This means that bank size and lending in advanced countries is associated with a decrease in bank risk adjusted ROA and, therefore, a decrease in the financial soundness of banks.

Tab. 3. Determinants of banking risk-taking in advanced and developing countries in Europe, 1995-2015

\begin{tabular}{|l|c|c|}
\hline & Model 1 (Advanced) & Model 2 (Developing) \\
\hline & $\mathrm{b} / \mathrm{se}$ & $\mathrm{b} / \mathrm{se}$ \\
\hline & $0.373^{* * *}$ & $0.455^{* *}$ \\
\hline L2.RISK_ADISK_AD & $(0.03)$ & $0.17)$ \\
\hline & $0.274^{* * *}$ & $(0.14)$ \\
\hline SIZE & $(0.04)$ & $0.158^{* *}$ \\
\hline & $-0.029^{* *}$ & $(0.12)$ \\
\hline LOANS_ASSETS & $(0.02)$ & $0.113^{*}$ \\
\hline & $-0.004^{*}$ & $(1.76)$ \\
\hline FOREIGN_BANKS & $(0.01)$ & $-0.018^{* *}$ \\
\hline & $-0.002^{* *}$ & $(0.03)$ \\
\hline FINANCIAL_FREE & $(0.00)$ & -0.008 \\
\hline & -0.002 & $(0.02)$ \\
\hline GDP_GROWTH & $(0.00)$ & $0.013^{*}$ \\
\hline & $0.052^{* * *}$ & $(0.03)$ \\
\hline INFLATION & $(0.01)$ & $0.059^{* *}$ \\
\hline & $0.031^{* *}$ & $(0.06)$ \\
\hline CONSTANT & $(0.01)$ & -0.255 \\
\hline & $1.081^{* *}$ & $(3.08)$ \\
\hline
\end{tabular}


Pobrane z czasopisma Annales H - Oeconomia http://oeconomia.annales.umcs.pl Data: 26/04/2023 14:29:10

\begin{tabular}{|l|c|c|}
\hline & Model 1 (Advanced) & Model 2 (Developing) \\
\hline Obs & 3955 & 725 \\
\hline \# banks & 318 & 63 \\
\hline AR1 & -6.4 & -1.2 \\
\hline p-value & 0.2 & 0.2 \\
\hline AR2 & -3.0 & -0.2 \\
\hline p-value & 0.6 & 0.8 \\
\hline Hansen test & 367.7 & 30.2 \\
\hline p-value & 0.9 & 0.7 \\
\hline
\end{tabular}

Note: The model is given by Eq. (2). The symbols have the following meaning: $R I S K \_A D$-risk adjusted ROA is given by Eq. 1, SIZE - logarithm of total bank's assets, LOANS_ASSETS - as the ratio of bank's loans to total assets (\%), FOREIGN_BANKS - foreign bank's assets among total bank's assets (\%), FINANCIAL_FREE - financial freedom is a measure of banking efficiency (\%), GDP_GROWTH - GDP annual rate (\%), INFLATION - inflation rate. The models have been estimated using the GMM estimator with robust standard errors. Standard Errors (se) are given in parentheses. $\#$ - means number of observations/banks/instruments, respectively. The p-value denotes significance levels at ${ }^{*} p<0.1$, ${ }^{* *} p<0.05,{ }^{* * *} p<0.01$, respectively.

Source: author's own study.

We found that the coefficient for foreign bank's ownership loads negatively and significantly, and the influence is stronger in developing countries and this is in line with Hypothesis 1. Intuitively, banks that have high levels of foreign capital take more risk and consequently lose stability in performance ratio. We also emphasized that bank's stability is negatively influenced by growth of financial freedom - measure of banking efficiency as well as a measure of independence from government control and interference in the financial sector, but this relation is not statistically significant. These findings do not confirm our Hypothesis 2, that financial liberalization increases the negative impact on banking. For the control variables at the national level-GDP growth has a positive, and significant effect on banking stability. Growth in GDP improves profitability and reduces volatility of ROA. It means that banks have stable results in economic growth. But this link is not positive during recession periods, where managers might take decision how to finance lending and reduce risk.

\section{Conclusions}

This paper contributes to the literature by analysing how foreign ownership and financial freedom affects bank's stability in developing and advanced economies in Europe over the 1995-2015 period. The results show a negative and significant relationship between foreign ownership and bank's stability. More importantly, this negative and significant relationship is held in the model, when we used risk adjusted ROA as the instability measure.

Our results also suggest that the channel through which the bank size impacts banking risk-taking differs across countries in Europe depending on their economic development. Firstly, in developed countries, the size of bank assets increases risk and makes the ROA more volatile, in developing countries, it increases financial sta- 
bility. Secondly, growth of foreign ownership in banking sector increases instability of bank's efficiency, given by risk adjusted ROA, and this relationship is stronger in developing countries. Thirdly, procyclicality of the banking sector means gradual changes in risk-taking and perceptions in decisions of banks. It follows the pattern of taking a risk during booms, and excessive aversion to taking a risk during busts.

Summing up the implications of banking risk in European countries confirms theoretical discussion about differences in a cross-country analysis and for different stages of country development. In this paper, we compliment the existing literature by providing new insights into the impact of foreign ownership on the degree of risk-taking of the European banks. The findings may constitute the source of information during the current debate on changes in the international regulation of the banking sector.

\section{Bibliography}

Abiad A., Detragiache E., Tressel T., A new database of financial reforms, "IMF Working Papers" 2008, No. 08/266.

Agoraki M.-E. K., Delis M.D., Pasiouras F., 2011, Regulations, competition and bank risk-taking in transition countries, "Journal of Financial Stability" 2011, No. 7,

DOI: https://doi.org/10.1016/j.jfs.2009.08.002.

Amidu M., Wolfe S., Does bank competition and diversification lead to greater stability? Evidence from emerging markets, "Review of Development Finance" 2013, No. 3.

Anginer D., Cerutti E., Martínez Pería M.S., Foreign Bank Subsidiaries'Default Risk during the Global Crisis: What Factors Help Insulate Affiliates from their Parents?, "Journal of Financial Intermediation" 2016, Vol. 29, DOI: http://dx.doi.org/10.1016/j.jfi.2016.05.004.

Angkinand A., Wihlborg C., Deposit insurance coverage, ownership, and banks' risk-taking in emerging markets, 2010, http://digitalcommons.chapman.edu/cgi/viewcontent.cgi?article=1026\&context=business_articles [access: 15.10.2017].

Arellano M., Bond S., Some tests of specification for panel data: Monte Carlo evidence and an application to employment equations, "Review of Economic Studies" 1991, No. 58.

Arellano M., Bover O., Another look at the instrumental variables estimation of error components models, "Journal of Econometrics" 1995, Vol. 68.

Bang J., Olivero M., Wu J., Do Foreign Banks Increase Competition? Evidence from Emerging Asian and Latin American Banking Markets, "Journal of Banking \& Finance” 2011, Vol. 35,

DOI: http://dx.doi.org/10.1016/j.jbankfin.2010.10.012.

Blundell R., Bond S., Initial conditions and moment conditions in dynamic panel data models, "Journal of Econometrics" 1998, No. 87.

Borio C., Furfine C., Lowe P., Procyclicality of the financial system and financial stability: issues and policy options, "BIS Papers" 2001, No. 1.

Brewer E., Kaufman G., Larry D., Bank Capital Ration Across Countries: Why Do They Vary?, "Journal of Financial Services Research" 2008, No. 34.

Brunnermeier M., Pedersen K.L.H., Market Liquidity and Funding Liquidity, "Review of Financial Studies" 2009, No. 22.

Cubillas E., González F., Financial liberalization and bank risk-taking: International evidence, "Journal of Financial Stability” 2014, Vol. 11, DOI: http://dx.doi.org/10.1016/j.jfs.2013.11.001.

De Haas R., Van Horen N., International shock transmission after the Lehman Brothers collapse: Evidence from syndicated lending, "American Economic Review: Papers \& Proceedings" 2012, Vol. 102(3). 
Dekle R., Mihye L., Do foreign bank affiliates cut their lending more than the domestic banks in a financial crisis?, "Journal of International Money and Finance" 2014, Vol. 50,

DOI: http://dx.doi.org/10.1016/j.jimonfin.2014.08.005.

Demirgüc-Kunt A., Detragiache E., Financial liberalization and financialfragility, "World Bank Policy Research Working" 1999, No. 1917.

Hovakimian A., Kane E.J., Effectiveness of capital regulation at US commercial banks, 1985-1994, "Journal of Finance" 2000, No. 55.

Ghosh A., How do derivative securities affect bank risk and profitability?: Evidence from the US commercial banking industry, "Journal of Risk Finance" 2017, Vol. 18(2),

DOI: http://dx.doi.org/10.1108/JRF-09-2016-0116.

Iannotta G., Nocera G., Sironi A., The impact of government ownership on bank risk, "Journal of Financial Intermediation" 2013, No. 22.

Jiménez G., Lopez J.A., Saurina J., How does competition affect bank risk-taking?, "Journal of Financial Stability" 2013, No. 9.

Kaminsky G., Reinhart C.M., The twin crises: the causes of banking and balance of payments problems, "American Economic Review" 1999, Vol. 89(3), DOI: https://doi.org/10.1257/aer.89.3.473.

Lassoued N., Houda S., Ben Rejeb Attia M., The impact of state and foreign ownership on banking risk: Evidence from the MENA countries, "Research in International Business and Finance" 2016, Vol. 36, DOI: https://doi.org/10.1016/j.ribaf.2015.09.014.

Luo Y., Tanna S., De Vita G., Financial openness: risk and bank efficiency: Cross-country evidence, "Journal of Financial Stability" 2016, No. 24.

Stiglitz J., Capital market liberalization, economic growth, and instability, "World Development" 2000, Vol. 28(6), DOI: https://doi.org/10.1016/S0305-750X(00)00006-1.

Tornell A., Westermann F., Martinez L., The Positive Link Between Financial Liberalization, Growth and Crises, "NBER Working Paper" 2004, No. 10293.

Wu J., Chen M., Jeon B.N., Wang R., Does foreign bank penetration affect the risk of domestic banks? Evidence from emerging economies, "Journal of Financial Stability" 2017, No. 31.

\section{Znaczenie zagranicznego kapitału właścicielskiego i liberalizacji finansowej dla ryzyka bankowego: analiza porównawcza w krajach europejskich}

Celem badania jest weryfikacja empiryczna odpowiedzi na pytanie, w jaki sposób udział zagranicznego kapitału właścicielskiego i liberalizacji finansowej wpływa na profil ryzyka sektora bankowego w Europie. Wykorzystując dane indywidualne z 381 banków europejskich w okresie 1995-2015 i metodę regresji panelowej, autorka udowadnia heterogeniczność czynników ryzyka bankowego. Analizie został poddany wskaźnik ROA ważony ryzykiem, który jest wykorzystywany jako miara niestabilności finansowej banków. Badanie stanowi istotny wkład do literatury i dotyczy grupy krajów z Europy Środkowo-Wschodniej oraz krajów rozwiniętych. Wyniki estymacji modelu wskazują na związek przyczynowy między ryzykiem bankowym a wzrostem sektora finansowego i gospodarki.

\section{The Relevance of Foreign Ownership and Financial Liberalization for Determining Banking Risk: A Comparative Analysis of European Countries}

The goal of this study is to empirically identify how foreign capital group and financial liberalization affect the risk profiles of the banking sector in Europe. Through a dataset that covers 381 European banks spanning the 1995-2015 period and the methodology of panel regression, the empirical findings document the heterogeneity of banking risk determinants. We examine the implications of banks' risk adjusted ROA that manifest themselves as spreading and growing instability. It also contributes to the literature by focusing on a group of countries from Central and Eastern and Advanced Europe that have not been studied before. The extended model provides a causal link between the risk in the banking sector and the growth of the financial sector and economy. 